\title{
EXCITATORY AMINO ACID BINDING SITES IN THE BASAL GANGLIA OF THE RAT: A QUANTITATIVE AUTORADIOGRAPHIC STUDY
}

\author{
R. L. Albin, R. L. Makowiec, Z. R. Hollingsworth, L. S. Dure IV, J. B. Penney \\ and A. B. YounG* \\ Department of Neurology, University of Michigan, Ann Arhor, MI 48109, IJ.S.A
}

\begin{abstract}
Quantitative receptor autoradiography was used to determine the distribution of excitatory amino acid binding sites in the basal ganglia of rat brain. $\alpha$-Amino-3-hydroxy-5-methylisoxazole-4propionic acid, $N$-methyl-D-aspartate, kainate, quisqualate-sensitive metabotropic and non- $N$-methyl-Daspartate, non-kainate, non-quisqualate glutamate binding sites had their highest density in striatum, nucleus accumbens, and olfactory tubercle. Kainate binding was higher in the lateral striatum but there was no medial-lateral striatal gradient for other binding sites. $N$-Methyl-D-aspartate and $\alpha$-amino-3hydroxy-5-methylisoxazole-4-propionic acid binding sites were most dense in the nucleus accumbens and olfactory tubercle. There was no dorsal-ventral gradient within the striatal complex for the other binding sites. Other regions of the basal ganglia had lower densities of ligand binding. To compare binding site density within non-striatal regions, binding for each ligand was normalized to the striatal binding density. When compared to the striatal complex, $\alpha$-amino-3-hydroxy-5-methylisoxazole-4-propionic acid and metabotropic binding sites had higher relative density in the globus pallidus, ventral pallidum, and subthalamic nucleus than other binding sites. Metabotropic binding also had a high relative density in the substantia nigra. Non- $N$-methyl-D-aspartate, non-kainate, non-quisqualate glutamate binding sites had a high relative density in globus pallidus, ventral pallidum, and substantia nigra. $N$-Methyl-D-aspartate binding sites had a low relative density in pallidum, subthalamic nucleus, substantia nigra and ventral tegmental area.

Our data indicate heterogeneous distribution of excitatory amino acid binding sites within rat basal ganglia and suggest that the character of excitatory amino acid-mediated neurotransmission within the basal ganglia is also heterogeneous.
\end{abstract}

The basal ganglia are a group of interconnected subcortical nuclei spanning the telencephalon, diencephalon, and mesencephalon. While the functions of the basal ganglia are incompletely understood, it is known from both human clinical and experimental animal studies that the basal ganglia are involved in the organization of a wide variety of motor and non-motor behaviors. Biochemical, physiological, behavioral, and immunocytochemical data indicate that excitatory amino acids (EAAs) are important neurotransmitters of afferents to basal ganglia nuclei and of some circuits within the basal ganglia (see below). The best studied of these pathways is the corticostriate projection, where biochemical, ${ }^{6,13,24,29,30,40,54,70,75,80,94}$ physiological, ${ }^{43,44,90,91}$ immunocytochemical, ${ }^{21}$ and $\left[{ }^{3} \mathrm{H}\right] \mathrm{D}$-aspartate retrograde tracing studies ${ }^{91}$ have provided strong evidence that the primary neurotrans-

*To whom correspondence should be addressed at: Neurology Service, Massachusetts General Hospital, Boston, MA 02114 , U.S.A.

Abbreviations: AMPA, $\alpha$-amino-3-hydroxy-5-methylisoxazole-4-propionic acid; EAA, excitatory amino acid; EP, entopeduncular nucleus; GP, globus pallidus; NMDA, $N$-methyl-D-aspartate; NNKQ, non-NMDA, nonkainate, non-quisqualate; OT, olfactory tubercle; PPN, pedunculopontine nucleus; SN, substantia nigra; STN, subthalamic nucleus; VP, ventral palladium; VTA, ventral tegmental area. mitter of corticostriate neurons is an EAA. In addition, other striatal afferents, including those from the amygdala, ${ }^{26}$ the parafascicular nucleus, ${ }^{26}$ and the subthalamic nucleus (STN) ${ }^{2.77}$ may utilize EAAs as a neurotransmitter. Other basal ganglia nuclei appear to receive EAAergic inputs. Recent physiological and immunocytochemical studies suggest that the STN, which sends substantial projections to the pallidum and substantia nigra ( $\mathrm{SN})$, is excitatory and uses an EAA as its neurotransmitter. ${ }^{2.38,62.77}$ Biochemical and tract-tracing studies have suggested that there is an EAAergic projection to the $\mathrm{SN}$ and ventral tegmental arca (VTA) from the frontal cortex. ${ }^{7,10.17,53}$ The STN itself appears to receive a large projection from cortex and physiological evidence indicates that this projection is EAAergic. ${ }^{1,49,78,79}$.

EAA receptors have been subdivided into subtypes based on their response to relatively selective agonists. ${ }^{56,98}$ These receptors appear to possess distinctive physiological properties. ${ }^{56,98}$ The kainate receptor, and the quisqualate-sensitive and $\alpha$-amino-3-hydroxy-5-methylisoxazole-4-propionic acid (AMPA)sensitive receptor mediate conventional fast synaptic neurotransmission by activation of ligand-gated ion channels. The $N$-methyl-D-aspartate (NMDA) receptor activates a cation channel which is gated by magnesium in a voltage-dependent fashion. NMDA receptors are thought to mediate some forms of 
synaptic plasticity. ${ }^{20.56}$ A quisqualate-sensitive, but AMPA-insensitive EAA receptor coupled to inositol phospholipid metabolism (the metabotropic receptor) has been described recently. ${ }^{87}$ The metabotropic receptor presumably produces neuromodulation rather than conventional fast neurotransmission. In addition to thesc relatively well-charactcrizcd receptor subtypes, we have described recently a neuronal $\left[{ }^{3} \mathrm{H}\right]$ glutamate binding site of unknown physiological significance and unique pharmacology. ${ }^{32}$ This nonNMDA, non-kainate, non-quisqualate (NNKQ) $\left[{ }^{3} \mathrm{H}\right]$ glutamate binding site has a unique regional distribution within the CNS and undergoes significant changes in regional distribution during postnatal development. ${ }^{32}$ The existence of EA $A$ receptor subtypes with distinctive physiological characteristics suggests that the postsynaptic effects of EAAs at a given synapse or within a given region are likely to be complex and possibly related to the relative density of EAA receptor subtypes. EAA receptor subtype distribution within the basal ganglia may play a major role in determining the character of EAA-mediated neurotransmission within specific basal ganglia nuclei.

Previous autoradiographic studies have identified EAA receptor subtypes within the basal ganglia. ${ }^{33,37,57,58,60,74,93}$ No study, however, has systematically analysed the distribution of all EAA receptor subtypes in these nuclei. Recent refinements in autoradiographic assays permit better delineation of EAA hinding sites. As a prelude to further studies on EAA function within the basal ganglia we used quantitative receptor autoradiography to determine the distribution of EAA binding sites within the basal ganglia of the rat.

\section{EXPERIMENTAI, PROCEDURES}

Materials

['H]Glutamate (specific activity, $46 \mathrm{Cl} / \mathrm{mmol}$ ) and $\left[{ }^{3} \mathrm{H}\right] \mathrm{kainate}$ (specific activity, $4.4 \mathrm{Ci} / \mathrm{mmol}$ ) wcre purchased from Amersham Inc. (Arlington Heights, IL). [ $\left.{ }^{3} \mathrm{H}\right] \mathrm{AMPA}$ (specific activity, $29 \mathrm{Ci} / \mathrm{mmol}$ ) was purchased from DuPont/NEN (Boston, MA). Non-radioactive quisqualate, AMPA and NMDA were purchased from Cambridge Research Biochemicals Inc. (Valley Stream, NY). The remaining reagents were purchased from Sigma Chemicals (St Louis, MO) and were of the highest possible purity.

\section{Tissue preparation}

Fifteen male Sprague-Dawley rats (Harlan Labs. Indianapolis, IN; weight, 175 $200 \mathrm{~g}$ ) were decapitated, their brains rapidly removed and frozen in powdered dry ice. Twenty-micrometer-thick sections were cut on a Lipshaw cryostat. Eight animals were sectioned in the coronal plane at five different rostrocaudal levels. These levels included the caudoputamen-nucleus accumbens-olfactory tubercle (OT), the globus pallidus (GP)-ventral pallidum (VP), the entopeduncular nucleus, the STN, and the SN...VTA. Seven animals were sectioned in a parasagittal plane at two different levels approximately 1.9 and $2.4 \mathrm{~mm}$ from the midline ${ }^{68}$ Sections were thaw-mounted onto gelatin-coated slides on a warming plate and stored at $-20 \mathrm{C}$ until the time of assay. All assays were run $2448 \mathrm{~h}$ after being killed. Eight animals (four cut in the coronal plane and four cut in the sagittal plane) were used for assay of kainate and NNKQ binding sites. Seven animals (four cut coronally and three parasagittally) were used for assay of AMPA. metabotropic and NMDA binding sites.

\section{Receptor autoradiography}

Triplicate slides for assay of both total and nonspecific binding of each binding site were obtained at every level of sectioning. Quantitative receptor autoradiography for AMPA and kainate binding sites was performed with $\left[{ }^{3} \mathrm{H}\right] \mathrm{AMPA}$ and $\left[{ }^{3} \mathrm{H}\right] \mathrm{kainate}$, respectively, using conventional autoradiographic techniques (Table 1). ${ }^{\circ *}$ NMDA binding sites were assayed with $\left[{ }^{3} \mathrm{H}\right]$ glutamate in the pres-

Table 1. Conditions for excitatory amino acid binding site assays*

\begin{tabular}{|c|c|c|c|c|c|}
\hline Binding site & Ligand & Concentration & Buffer & Blockers & Blank \\
\hline NMDA & {$\left[{ }^{3} \mathrm{H}\right] \mathrm{GLU}$} & $60 \mathrm{nM}$ & $\begin{array}{c}50 \mathrm{mM} \\
\text { Tris-acetate } \\
\text { pH } 7.4\end{array}$ & $\begin{array}{c}2.5 \mu \mathrm{M} \text { QUIS } \\
100 \mu \mathrm{M} \text { KA }\end{array}$ & $1 \mathrm{mM}$ NMDA \\
\hline AMPA & {$\left[{ }^{3} \mathrm{H}\right] \mathrm{AMPA}$} & $34 \mathrm{nM}$ & $\begin{array}{c}50 \mathrm{mM} \\
\text { Tris } \mathrm{HCl}+ \\
2.5 \mathrm{mM} \mathrm{CaCl} \\
+30 \mathrm{mM} \mathrm{KSCN} \\
\text { pH } 7.2 \dagger\end{array}$ & & $1 \mathrm{mM} \mathrm{GLU}$ \\
\hline MET & {$\left[{ }^{3} \mathrm{H}\right] \mathrm{GLU}$} & $100 \mathrm{nM}$ & $\begin{array}{c}50 \mathrm{mM} \\
\text { Tris- } \mathrm{HCl}+ \\
2.5 \mathrm{mM} \mathrm{CaCl}_{2} \\
+30 \mathrm{mM} \mathrm{KSCN} \\
\text { pH } 7.2 \dagger\end{array}$ & $\begin{array}{c}100 \mu \mathrm{M} \text { NMDA } \\
10 \mu \mathrm{M} \text { AMPA }\end{array}$ & $2.5 \mu \mathrm{M}$ QUIS \\
\hline $\mathrm{KA}$ & {$\left[{ }^{3} \mathrm{H}\right] \mathrm{KA}$} & $60 \mathrm{nM}$ & $\begin{array}{c}50 \mathrm{mM} \\
\text { Tris-acetate } \\
\text { pH } 7.2\end{array}$ & & $100 \mu \mathrm{M} \mathrm{KA}$ \\
\hline NNKQ & {$\left[{ }^{3} \mathrm{H}\right] \mathrm{GLU}$} & $200 \mathrm{nM}+$ & $\begin{array}{c}50 \mathrm{mM} \\
\text { Tris- } \mathrm{HCl}+ \\
2.5 \mathrm{mM} \mathrm{CaCl} \\
\mathrm{pH} 7.2\end{array}$ & $\begin{array}{l}1 \mathrm{mM} \text { NMDA } \\
2.5 \mu \mathrm{M} \text { QUIS } \\
1 \mathrm{mM} \mathrm{KA}\end{array}$ & I mM GLU \\
\hline
\end{tabular}

*All steps performed at $4{ }^{\circ} \mathrm{C}$.

$†$ Rinse huffer without KSCN.

${ }_{+}^{+}$Specific activity diluted to $6.9 \mathrm{Ci} / \mathrm{mmol}$ with non-radioactive glutamate (GLU).

KA, kainate; MET, metabotropic; QUIS, quisqualate. 
ence of blocking agents (Table 1) ${ }^{98}$ Metabotropic binding sites were assayed with $\left[{ }^{3} \mathrm{H}\right]$ glutamate in the presence of selective blockers according to the method of Cha et al..$^{14}$ (Table 1) and the NNKQ binding sites were assayed with [ ${ }^{3}$ HIglutamate as previously described (Table 1). ${ }^{33}$

For kainate binding sites, the concentration of radioactive ligand was $60 \mathrm{nM}$ and nonspecific binding was assessed with the addition of $100 \mu \mathrm{M}$ kainate. For AMPA binding sites, the concentration of [ $\left.{ }^{3} \mathrm{H}\right] \mathrm{AMPA}$ was $34 \mathrm{nM}$, and nonspecific binding was assessed with the addition of $1 \mathrm{mM}$ glutamate. For NMDA binding sites, the concentration of $\left[{ }^{3} \mathrm{H}\right]-$ glutamate was $60 \mathrm{nM}$ and nonspecific binding was assessed with addition of $1 \mathrm{mM}$ NMDA. Metabotropic binding site density was assayed with $100 \mathrm{nM}\left[{ }^{3} \mathrm{H}\right.$ lglutamate, and nonspecific binding was measured with the addition of $2.5 \mu \mathrm{M}$ quisqualate. NNKQ binding sites were measured with $30 \mathrm{nM}\left[{ }^{3} \mathrm{H}\right]$ glutamate diluted with $170 \mathrm{nM}$ non-radioactive glutamate (final specific activity, $6.9 \mathrm{Ci} / \mathrm{mmol}$ ) in the presence of $1 \mathrm{mM}$ NMDA, $1 \mathrm{mM}$ kainate, and $2.5 \mu \mathrm{M}$ quisqualate, and nonspecific binding was measured with $1 \mathrm{mM}$ glutamate. For AMPA, kainate, and NMDA binding, nonspecific binding represented less than $10 \%$ of total binding. Nonspecific binding was approximately $25 \%$ of total NNKQ binding and approximately $50 \%$ of total metabotropic binding.

All assays were performed in an identical manner. Slides were warmed to room temperature, immersed in incubation buffer at $4^{\circ} \mathrm{C}$ for $30 \mathrm{~min}$ and dricd under a strcam of cool air. Sections were then placed in incubation buffer at $4^{\circ} \mathrm{C}$ containing a single concentration of radioactive ligand (Table 1) and appropriate blocking agents (Table 1) for $45 \mathrm{~min}$. Incubation was terminated by removal of slides from the ligand solution and rapid rinsing with four 4-ml squirts of $4^{\circ} \mathrm{C}$ buffer followed by two $3-\mathrm{ml}$ squirts of $2.5 \%$ glutaraldehyde in acetone. Slides were then dried under a stream of hot air and apposed to tritium-sensitive film (Hyperfilm, Amersham) in light-tight cassettes along with standards containing known amounts of radioactivity. After two to six weeks, films were developed in Kodak D-19.

\section{Data analysis}

Ligand binding was quantitated with computer-assisted densitometry using the MCID system (Imaging Research Inc., St Catharines, Ontario). To quantify ligand binding density, the optical density of co-exposed standards was determined and a standard curve generated by fitting standard values with a fourth-degree polynomial regression equation. ${ }^{67}$ Standards were either specially made ${ }^{14} \mathrm{C}$ plastic standards ${ }^{67}$ or commercial ${ }^{14} \mathrm{C}$ plastic standards (ARC Inc., St Louis, MO), both calibrated against previously described ${ }^{3} \mathrm{H}$-brain paste standards. ${ }^{67}$ The ${ }^{1} \mathrm{H}$-brain paste standards are constructed to give a known amount of radioactivity per picomole of protein. ${ }^{67}$ Use of the standards and derived standard curve allows conversion of areal optical density to $\mathrm{pmol} / \mathrm{mg}$ protein values. ${ }^{67}$ This technique does assume, however, that protein concentration is reasonably uniform across brain regions. Areas read included the medial striatum, lateral striatum, nucleus accumbens, OT, GP, ventral pallidum (VP), entopeduncular nucleus (EP), STN, and VTA. Medial striatum and lateral striatum were read separately because hodological and behavioral studies indicate that these areas have different functional features. ${ }^{9,55,71}$ The striatum viewed in the coronal plane was bisected to distinguish lateral striatum from medial striatum. When comparing data from lateral striatum and medial striatum, only readings from coronally sectioned animals were used. It was impossible to reliably differentiate substantia nigra pars compacta from substantia nigra pars reticulata and SN readings are an aggregate of the two regions weighted towards the pars reticulata because of its greater extent. All regions were read with a variable size cursor to allow sampling of the entire area of the structure(s) of interest present on each film. Assay of receptors with a single concentration of ligand does not allow strict comparison of receptor subtype density. Performance of saturation or displacement curves for small structures such as the STN, EP, and VTA is quite difficult. To assess the relative density of receptor subtypes within non-striatal basal ganglia nuclei, we normalized the density of binding sites within nonstriatal nuclei by calculating the percentage of striatumnucleus accumbens-OT complex binding site density for binding sites within non-striatal nuclei (Table 2). Since receptor density for all ligands (see below) was quite high in the striatal complex, the percentage of striatal binding serves as a basis for a comparative index of absolute receptor density.

Differences between the amount of given ligand bound within different areas of the same region were assessed with a paired $t$-test. Areas compared with the $t$-test included the lateral striatum and medial striatum, dorsal striatum (mean of lateral striatum and dorsal striatum from the coronally sectioned animals averaged with dorsal striatum from parasagittally sectioned animals) and ventral striatum (mean of nucleus accumbens and OT), and the GP and VP. To compare statistically the density of different binding sites within non-striatal regions, the percentages of striatal complex binding for each binding site in each non-striatal region were compared with each other using one-way analysis of variance followed by post hoc Newman-Keuls testing for individual comparisons.

\section{RESULTS}

\section{Striatum nucleus accumbens olfactory tubercle}

Among basal ganglia nuclei, these three regions had the highest density of all EAA binding sites (Table 2, Figs 1-4). With the exception of kainate binding, the density of ligand binding was similar between the medial striatum and lateral striatum (Tables 2, 3, Figs 1, 3). Kainate binding sites were slightly but significantly more dense in the lateral striatum (Tables 2, 3, Fig. 3). Kainate, metabotropic, and NNKQ binding sites had similar density in the striatum, nucleus accumbens, and OT (Tables 2, 3, Figs 1, 3, 4). NMDA and AMPA binding sites, however, had a dorsal-ventral density gradient with highest density of binding in the nucleus accumbens and OT (Tables 2, 3, Figs 1, 2).

\section{Globus pallidus-ventral pallidum}

In all assays the density of ligand binding was substantially lower in the GP and VP than in the striatum-nucleus accumbens-OT (Table 2, Figs 1-4). VP, however, had a consistently higher density of bound ligand than GP (Tables 2, 3, Figs 1-4). Relative to the striatal regions, there were some differences between receptor subtypes in the GP-VP. GP, NMDA and kainate binding sites had particularly low densities relative to the striatum (Tables 2, 3, Figs 2, 3). AMPA, metabotropic, and NNKQ binding sites had greater relative densities than NMDA or kainate binding sites in the GP (Tables 2, 3) and these differences were statistically significant (Table 3). In the VP, metabotropic, kainate, AMPA, and NNKQ binding had higher relative densities than NMDA binding sites (Tables 2,3). Analysis of variance indicated that metabotropic, kainate, AMPA, and NNKQ binding sites comprised a single 
Table 2. Density of excitatory amino acid binding sites in rat basal ganglia

\begin{tabular}{|c|c|c|c|c|c|}
\hline Region & NMDA & AMPA & MET & $\mathrm{KA}$ & NNKQ \\
\hline Lateral striatum $\dagger$ & $\begin{array}{c}0.673 \\
(0.016)\end{array}$ & $\begin{array}{c}2.417 \\
(0.031)\end{array}$ & $\begin{array}{c}0.694 \\
(0.053)\end{array}$ & $\begin{array}{c}1.044 \\
(0.172)\end{array}$ & $\begin{array}{c}1.513 \\
(0.193)\end{array}$ \\
\hline Medial striatumt & $\begin{array}{l}0.676 \\
(0.06)\end{array}$ & $\begin{array}{c}2.559 \\
(0.082)\end{array}$ & $\begin{array}{c}0.738 \\
(0.076)\end{array}$ & $\begin{array}{c}0.958 \\
(0.179)\end{array}$ & $\begin{array}{c}1.493 \\
(0.140)\end{array}$ \\
\hline Dorsal striatum & $\begin{array}{c}0.68 \\
(0.016)\end{array}$ & $\begin{array}{c}2.287 \\
(0.105)\end{array}$ & $\begin{array}{c}0.734 \\
(0.035)\end{array}$ & $\begin{array}{c}0.894 \\
(0.091)\end{array}$ & $\begin{array}{c}1.500 \\
(0.167)\end{array}$ \\
\hline Nucleus accumbens & $\begin{array}{c}1.002 \\
(0.039)\end{array}$ & $\begin{array}{c}2.712 \\
(0.286)\end{array}$ & $\begin{array}{c}0.767 \\
(0.084)\end{array}$ & $\begin{array}{l}0.9843 \\
(0.091)\end{array}$ & $\begin{array}{c}1.527 \\
(0.133)\end{array}$ \\
\hline OT & $\begin{array}{c}1.25 \\
(0.063)\end{array}$ & $\begin{array}{c}2.583 \\
(0.322)\end{array}$ & $\begin{array}{c}0.834 \\
(0.093)\end{array}$ & $\begin{array}{c}1.015 \\
(0.093)\end{array}$ & $\begin{array}{c}1.373 \\
(0.140)\end{array}$ \\
\hline Ventral striatum $\$$ & $\begin{array}{c}1.127 \\
(0.031)\end{array}$ & $\begin{array}{c}2.666 \\
(0.309)\end{array}$ & $\begin{array}{c}0.818 \\
(0.086)\end{array}$ & $\begin{array}{c}0.997 \\
(0.086)\end{array}$ & $\begin{array}{c}1.427 \\
(0.133)\end{array}$ \\
\hline Striatal complex* & 0.903 & 2.467 & 0.772 & 0.975 & 1.500 \\
\hline Globus pallidus & $\begin{array}{c}0.081 \\
(0.012) \\
9 \%\end{array}$ & $\begin{array}{c}0.626 \\
(0.054) \\
25 \%\end{array}$ & $\begin{array}{c}0.181 \\
(0.03) \\
23 \%\end{array}$ & $\begin{array}{c}0.138 \\
(0.01) \\
14 \%\end{array}$ & $\begin{array}{c}0.533 \\
(0.060) \\
36 \%\end{array}$ \\
\hline VP & $\begin{array}{c}0.173 \\
(0.033) \\
19 \%\end{array}$ & $\begin{array}{c}0.864 \\
(0.036) \\
35 \%\end{array}$ & $\begin{array}{c}0.363 \\
(0.045) \\
47 \%\end{array}$ & $\begin{array}{c}0.443 \\
(0.030) \\
45 \%\end{array}$ & $\begin{array}{c}0.740 \\
(0.087) \\
49 \%\end{array}$ \\
\hline $\mathrm{EP}$ & $\begin{array}{c}0.064 \\
(0.006) \\
7 \%\end{array}$ & $\begin{array}{c}0.41 \\
(0.010) \\
16 \%\end{array}$ & $\begin{array}{c}0.159 \\
(0.030) \\
21 \%\end{array}$ & $\begin{array}{c}0.233 \\
(0.037) \\
23 \%\end{array}$ & $\begin{array}{c}0.280 \\
(0.027) \\
19 \%\end{array}$ \\
\hline STN & $\begin{array}{c}0.161 \\
(0.015) \\
18 \%\end{array}$ & $\begin{array}{c}0.778 \\
(0.051) \\
31 \%\end{array}$ & $\begin{array}{c}0.377 \\
(0.059) \\
49 \%\end{array}$ & $\begin{array}{c}0.285 \\
(0.042) \\
29 \%\end{array}$ & $\begin{array}{c}0.223 \\
(0.053) \\
15^{\%} \%\end{array}$ \\
\hline $\mathrm{SN}$ & $\begin{array}{c}0.112 \\
(0.014) \\
12 \%\end{array}$ & $\begin{array}{c}0.578 \\
(0.025) \\
23 \%\end{array}$ & $\begin{array}{c}47 \% \\
0.259 \\
(0.038) \\
34 \%\end{array}$ & $\begin{array}{c}0.193 \\
(0.042) \\
20 \%\end{array}$ & $\begin{array}{c}0.613 \\
(0.040) \\
41 \%\end{array}$ \\
\hline VTA & $\begin{array}{c}0.188 \\
(0.031) \\
20 \%\end{array}$ & $\begin{array}{c}0.450 \\
(0.030) \\
18 \%\end{array}$ & $\begin{array}{c}0.11 \\
(0.051) \\
14 \%\end{array}$ & $\begin{array}{c}0.148 \\
(0.047) \\
15 \%\end{array}$ & $\begin{array}{c}0.360 \\
(0.053) \\
24 \%\end{array}$ \\
\hline
\end{tabular}

Units are pmol/mg protein (S.E.M.). Percentages are percentage of binding in region as percentage of binding in the striatal complex.*

*To correct for the greater extent of the dorsal striatum, the striatal complex mean was calculated by adding mean of dorsal striatum twice to means of nucleus accumbens and OT and dividing by four.

tMedial and lateral striatum measurements from animals sectioned in coronal plane.

${ }_{\ddagger}^{\ddagger}$ Mean of lateral and medial striatum in coronal sections averaged with striatum from parasagittal sections.

$\S$ Mean of nucleus accumbens and $O T$.

KA, kainate; MET, metabotropic.

Table 3. Results of statistical analysis

\begin{tabular}{lcccccc}
\hline t-Test results* & & & & \\
\hline Regions compared & NMDA & AMPA & MET & KA & NNKQ \\
\hline Lateral striatum vs medial striatum & NS & NS & NS & $P<0.025$ & NS \\
Dorsal striatum vs ventral striatum & $P<0.001$ & $P<0.05$ & NS & NS & NS \\
GP vs VP & $P<0.01$ & $P<0.05$ & $P<0.001$ & $P<0.001$ & $P<0.002$ \\
\hline
\end{tabular}

ANOVA resultst

\begin{tabular}{ll}
\hline GP & $P<0.0001 ;$ NNKQ $>$ MET $(P<0.05), \mathrm{KA}(P<0.01), \mathrm{NMDA}(P<0.01)$, \\
VP & AMPA KA $(P<0.05), \mathrm{NMDA}(P<0.01), \mathrm{MET}>\mathrm{NMDA}(P<0.05)$ \\
EP & $P<0.001 ;$ NNKQ, KA, MET, AMPA NMDA $(P<0.05)$ \\
SIN & $P<0.02 ;$ NNKQ, KA, MET NMDA $(P<0.05)$ \\
& $P<0.0001 ;$ MET $>$ NNKQ $(P<0.01), \mathrm{KA}(P<0.01)$, AMPA \\
SN & $(P<0.05)$, NMDA $(P<0.01)$ \\
& $P<0.0001 ;$ NNKQ $>$ NMDA $(P<0.01)$, AMPA $(P<0.01)$, \\
VTA & MET $(P<0.05), \mathrm{KA}(P<0.01), \mathrm{MET}>\mathrm{NMDA}(P<0.01)$ \\
\hline
\end{tabular}

* Results of paired $t$-test.

†Results of analysis of variance with significance of one-way NNOVA followed by results of significant post ho' Newman-Keuls individual comparisons. Individual Newman-Keuls comparisons that are not significant are not shown. KA, kainate; MET, metabotropic; NS, not significant, 

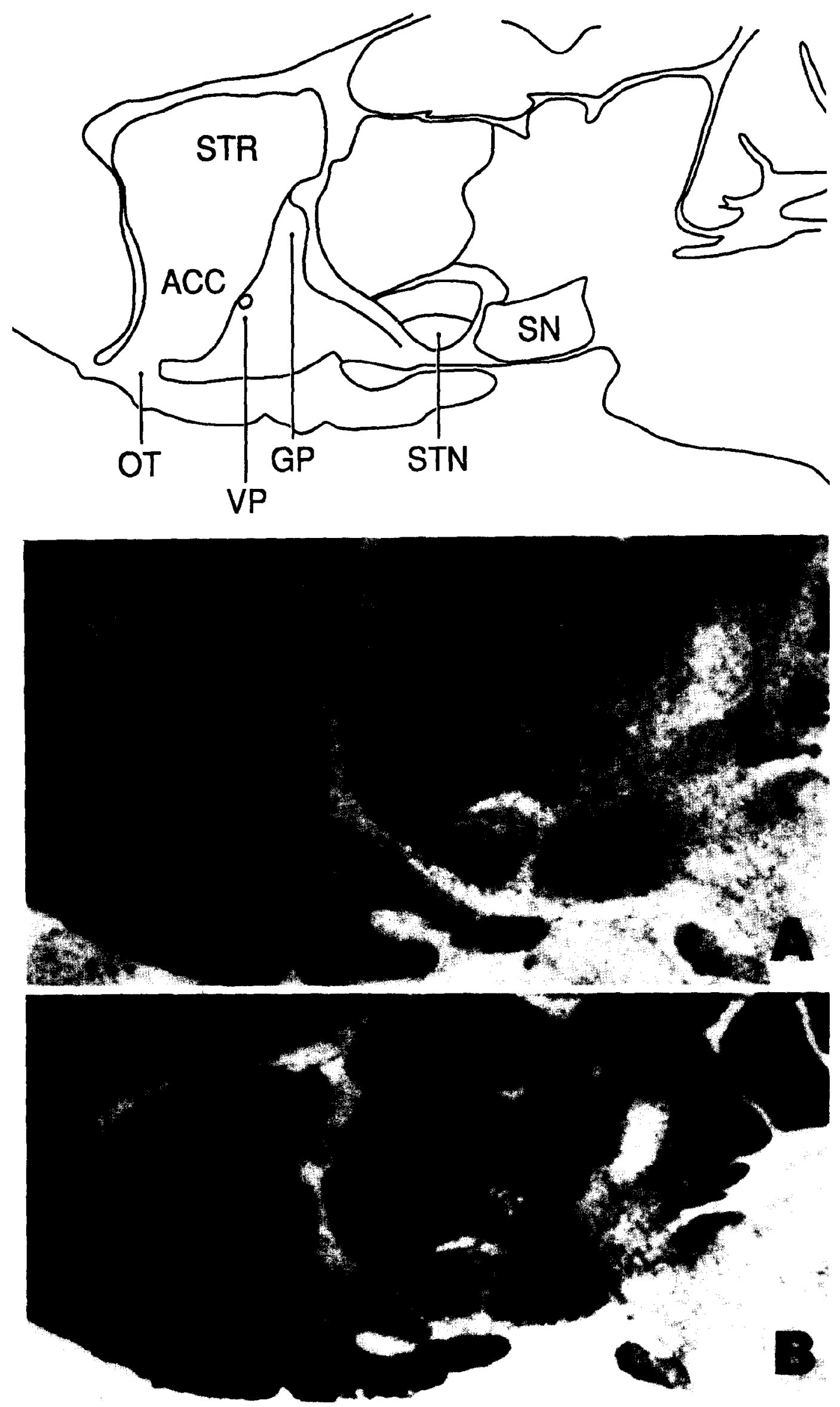

Fig. 1. A, B (caption overleaf). 


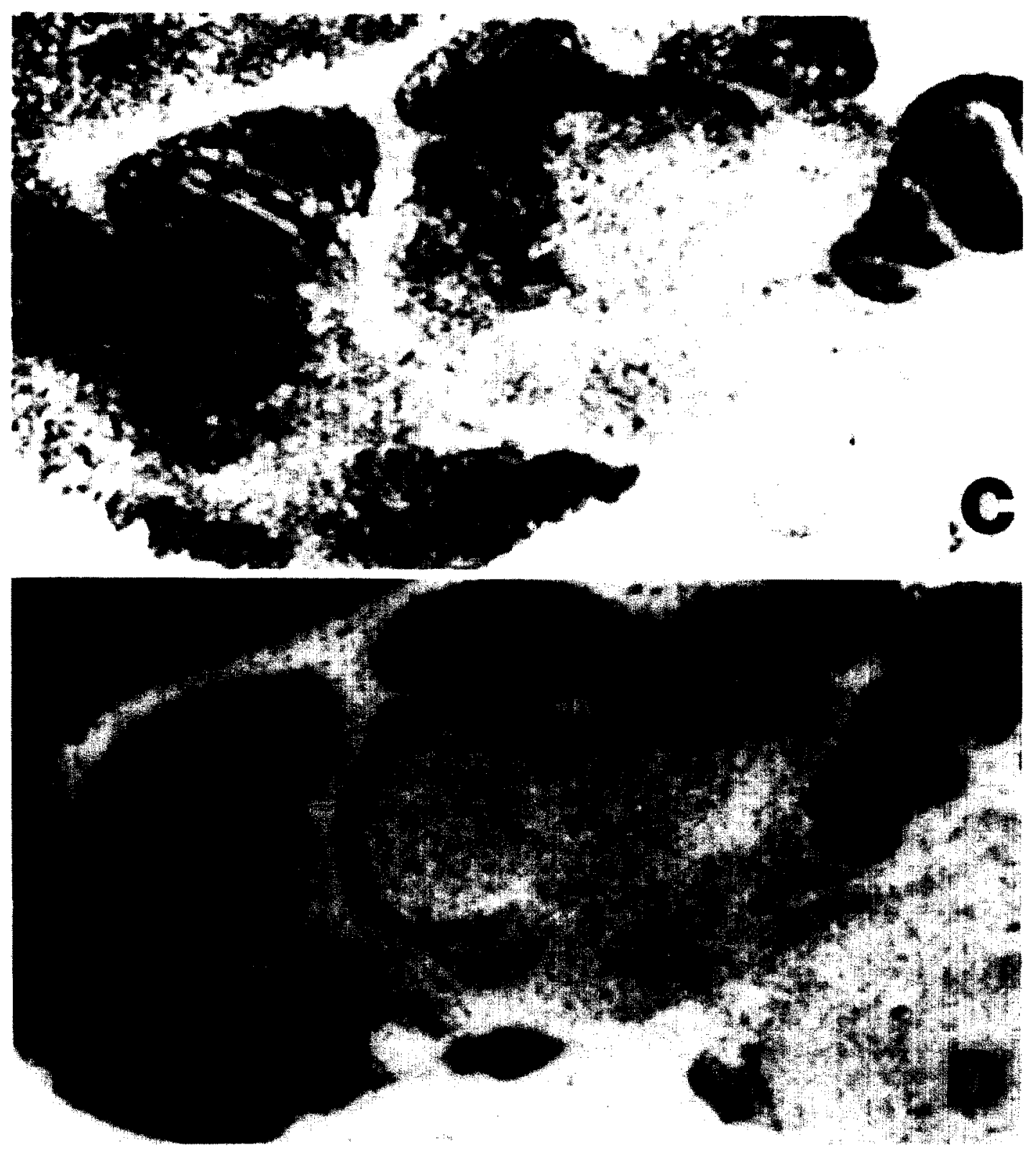

(34) 34 

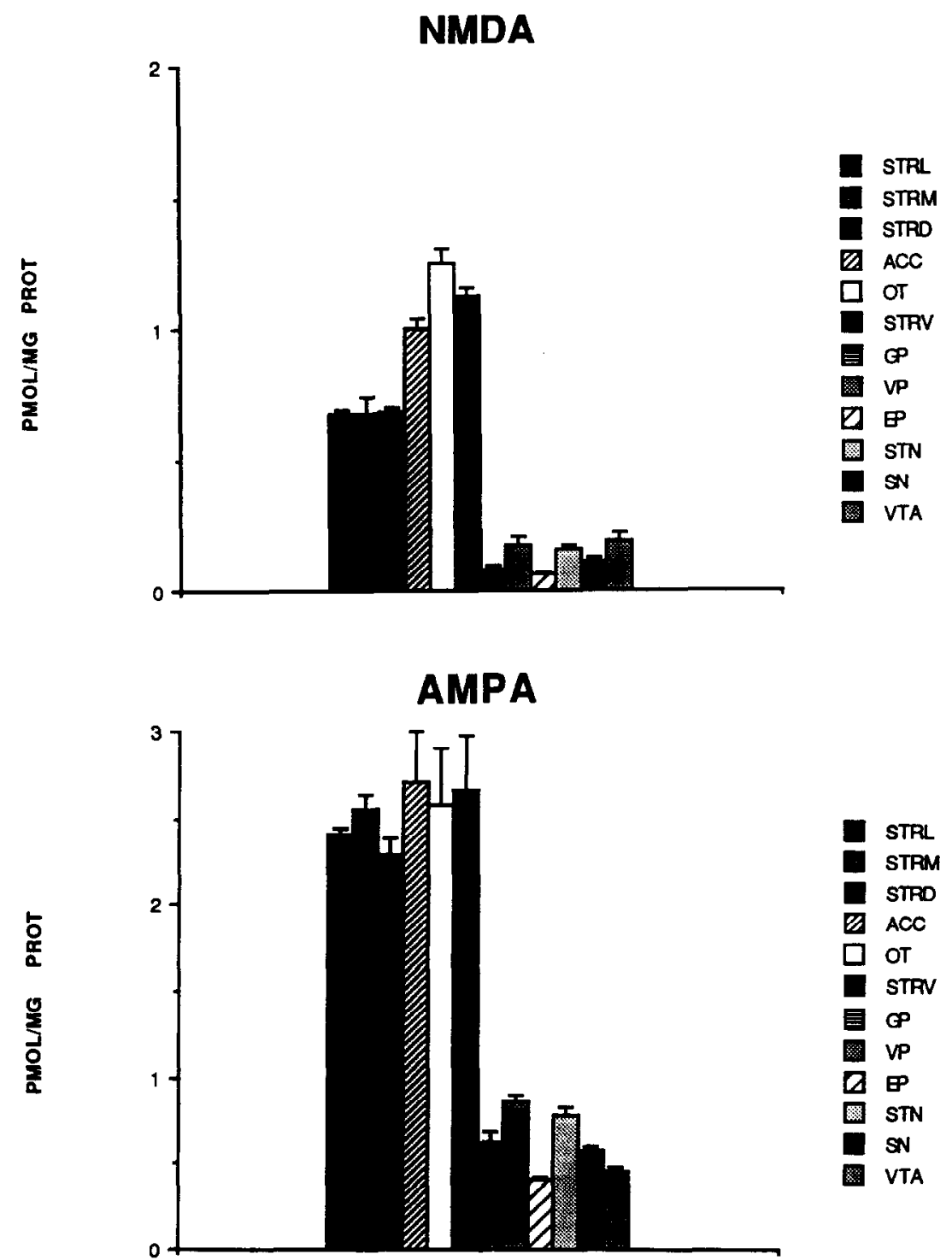

Fig. 2. Histograms of NMDA and AMPA binding site density in the basal ganglia. Error bars are S.E.M. STRL, lateral striatum; STRM, medial striatum; STRD, dorsal striatum; ACC, nucleus accumbens; STRV, ventral striatum.

group which was significantly different from NMDA binding sites (Table 3).

\section{Entopeduncular nucleus}

This region had a low relative density of all binding site subtypes (Table 2, Figs 1-4). As with the VP, the relative density of NMDA binding sites was lower than AMPA, metabotropic, kainate, and NNKQ relative binding site density with the relative densities of the latter four binding sites forming one group (Table 3).

\section{Subthalamic nucleus}

The relative density of NMDA and NNKQ binding sites was low (Tables 2, 3, Figs 2, 4). AMPA and kainate binding site densities were almost one-third of striatal complex binding and metabotropic binding site density was almost $50 \%$ of striatal complex

Fig. 1. Parasagittal autoradiographs of EAA binding sites in the basal ganglia. (A) NMDA, (B) AMPA, (C) metabotropic, (D) kainate, (E) NNKQ. STR, dorsal striatum; ACC, nucleus accumbens. Metabotropic binding site image prepared by digital subtraction of $\left[{ }^{3} \mathrm{H}\right]$ glutamate binding under metabotropic binding site conditions (see Table 1 and text) in the presence of $2.5 \mu \mathrm{M}$ quisqualate from total $\left[{ }^{3} \mathrm{H}\right]$ glutamate binding under metabotropic binding site conditions. Digital subtraction is done by computationally superimposing images from two closely adjacent sections and computing the difference of superimposed pixels. An image is constructed using the derived values for individual pixels. Digital subtraction is done with images from this assay because of the relatively high nonspecific binding. Magnification $=\times 10$ prior to reduction. 


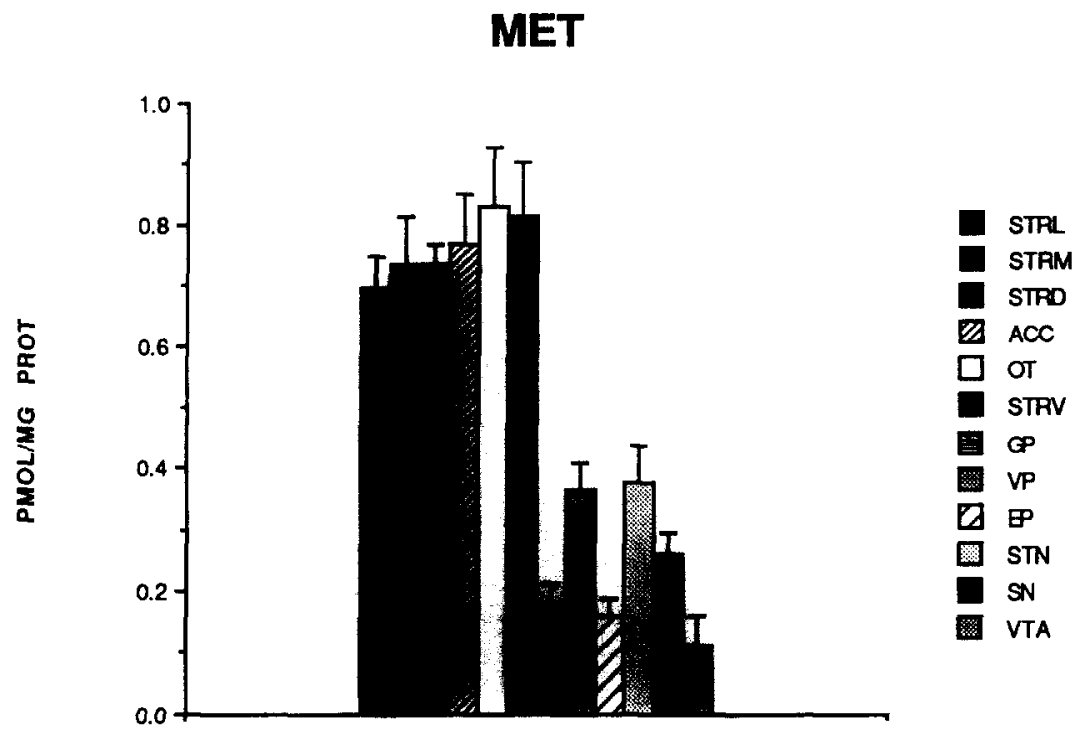

KA

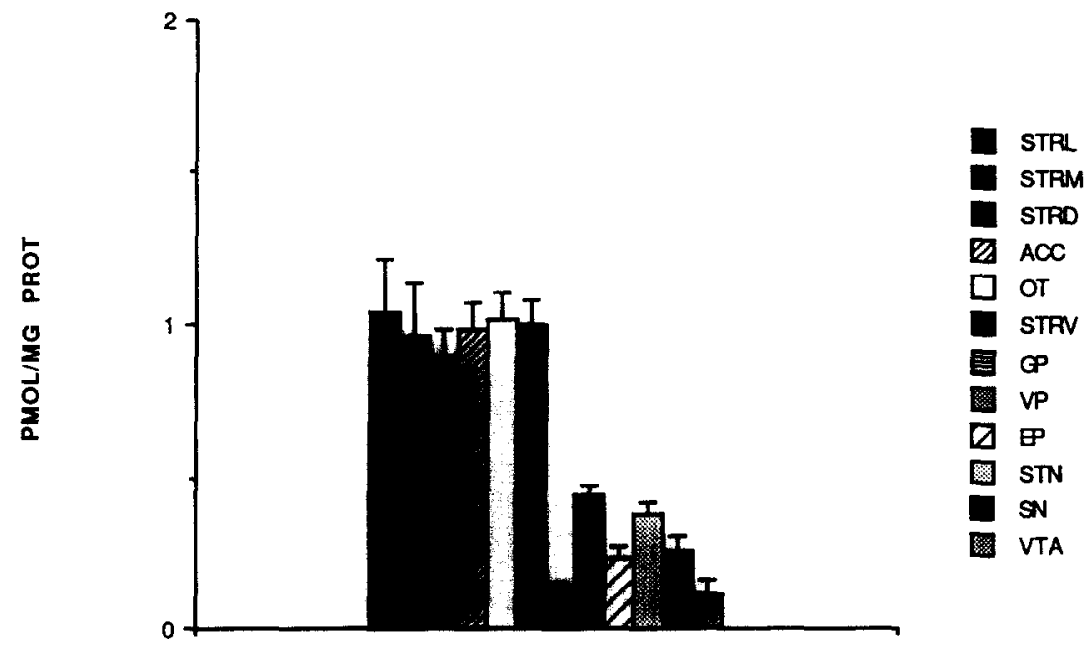

Fig. 3. Histograms of metabotropic (MET) and kainate (KA) binding site density in the basal ganglia. Abbreviations and error bars as for those of Fig. 2.

binding (Table 2, Figs 2, 3). Only the relative density of metabotropic binding was statistically distinguishable from the relative density of other binding sites (Table 3).

\section{Substantia nigra-ventral tegmental area}

The relative density of all binding sites was low in SN and VTA with the exception of metabotropic and NNKQ binding in the SN (Tables 2, 3, Figs 1-4). The latter was approximately $40 \%$ of striatal complex binding (Table 2, Fig. 4). The relative densities of metabotropic and NNKQ binding were significantly different from the relative densities of the other binding sites (Table 3 ). There were no significant differences among relative densities of binding sites in the VTA (Tables 2, 3).

\section{DISCUSSION}

All nuclei of the basal ganglia possessed EAA binding sites but EAA binding site subtypes were distributed inhomogeneously in rat basal ganglia. Strict comparison of the total density $\left(B_{\max }\right)$ of binding site subtypes within a given region was not possible using single ligand concentrations. Scatchard analyses, however, were not feasible in several regions due to their small size. Nonetheless, by comparing the amount of bound ligand relative to binding within the striatum-nucleus accumbens -OT complex, a region with a high density of all EAA binding site subtypes, it is possible to approximate the relative density of EAA binding site subtypes within and among basal ganglia nuclei. This type of analysis assumes that 


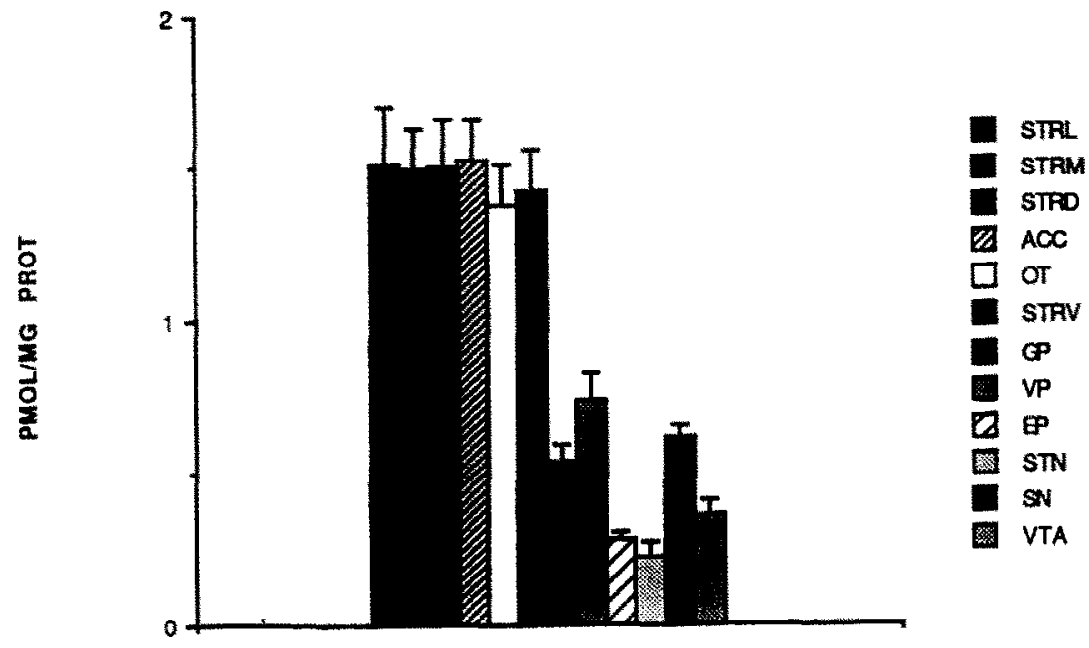

Fig. 4. Histogram of NNKQ binding site density in the basal ganglia. Abbreviations and error bars as for Fig. 2.

receptor affinity is reasonably similar in different basal ganglia nuclei. Prior studies of EAA binding sites have found little variation in the affinity of EAA binding sites between regions with the exception of NMDA binding sites which may exist in both agonist-preferring and antagonist-preferring forms in different regions. ${ }^{33,58,59}$

\section{Striatal complex}

The binding site density differences between basal ganglia nuclei are most marked by the higher density of all binding sites in the striatum-nucleus accumbens-OT complex than other nuclei of the basal ganglia. Of all basal ganglia nuclei, the striatum-nucleus accumbens - OT complex probably receives the greatest amount of EAAergic innervation. In addition to the massive and wellcharacterized input from neocortex to the striatum proper, ${ }^{23,24,29,30,40,54,70,75,80,94}$ the striatum nucleus accumbens-OT complex also receives probable EAAergic input from the hippocampal complex, ${ }^{94}$ amygdala, ${ }^{26,94,95}$ and primary offactory cortex ${ }^{26}$ The striatum-nucleus accumbens-OT complex may also receive EAAergic afferents from the intralaminar nuclei of the thalamus. Retrograde $\left[{ }^{3} \mathrm{H}\right] \mathrm{D}$-aspartate transport studies indicate that these nuclei may be EAAergic. ${ }^{26}$ Studies of striatal EAA uptake after parafascicular nucleus lesions, however, do not support this notion. ${ }^{65}$ The striatal complex also receives a potentially EAAergic input from the STN. While the STN-striatal projection is relatively modest in rat, ${ }^{36,48}$ in primates and cat it appears to be a more substantial striatal afferent. ${ }^{8,88}$ The relatively high density of all EAA binding sites within all components of the striatum-nucleus accumbens-OT complex emphasizes the similarity of dorsal striatum, nucleus accumbens, and OT. ${ }^{3}$
Our NMDA, AMPA, and kainate data are consistent with previous studies of striatal EAA binding sites in rat brain. ${ }^{33,37.57,58,60.93}$ Our results correlate with studies showing that intrastriatal infusion of agents active at either NMDA, AMPA, or kainate receptors produce prominent behavioral effects. ${ }^{22,41,45.85}$ Our metabotropic binding data are also compatible with evidence that ghtamate and quisqualate agonists are potent stimulators of inositol phospholipid turnover in striatal slices and striatal neurons in primary culture. ${ }^{64.83,96}$ Autoradiographic investigations of inositol triphosphate receptors have shown a high density in the striatum. ${ }^{97}$ Available data suggest that EAA binding sites are predominantly located on striatal neurons though some data suggests the presence of presynaptic EAA receptors on corticostriate and nigrostriatal dopaminergic terminals. 15.23,35 $^{2}$

Within the striatum-nucleus accumbens-OT complex, our results suggest differences in EAA binding site distribution. Kainate binding was significantly higher in the lateral striatum than the medial striatum, and there is a dorsal-ventral gradient of NMDA and AMPA binding site density with highest density in the ventral striatum and lowest in the dorsal striatum. One possible explanation for this gradient is the greater cellular density of the nucleus accumbens and OT, especially when compared with the dorsal striatum where it is penetrated by myelinated bundles of corticofugal axons. Myelin absorbs tritium emissions, and this "quenching" may cause underestimates of ligand binding. ${ }^{27}$ Kainate, metabotropic, and NNKQ binding sites, however, have no dorsal-ventral density gradient. The distributions of these binding sites cannot be attributed to neuronal density or white matter gradients and suggest that there is a real dorsal-ventral gradient in NMDA and AMPA binding site density. 
Non-striatal nuclei

Another dorsal-ventral gradient exists between the dorsal and ventral pallidum. In this situation, however, all EAA binding site subtypes are more dense in VP than in GP. Due to the fact that the GP is traversed by numerous fibers of passage, neuronal density is higher in VP than GP. Difference in neuronal density is a likely explanation for the higher density of receptors and NNKQ binding in VP than in GP. In addition, many of the fibers passing through the GP are myelinated, and white matter quenching could contribute to the apparently lower density of EAA binding sites in GP. While binding studies with ${ }^{14} \mathrm{C}$-labeled ligands would be necessary to systematically evaluate the possible role of quenching, our previous experience with $\left[{ }^{14} \mathrm{C}\right]$ glutamate binding suggests that white matter quenching is not at major determinant of regional differences in binding site density. ${ }^{34}$ Within the GP, AMPA, metabotropic, and NNKQ binding sites had higher relative densities compared to the striatal complex than NMDA or kainate binding sites. GP receives potentially EAAergic inputs from the parafascicular nucleus, ${ }^{47}$ and a substantial projection from the STN. ${ }^{48} \mathrm{VP}$ also receives a projection from the $\mathrm{STN}^{36}$ and Fuller et al. have used $\left[{ }^{3} \mathrm{H}\right] \mathrm{D}$-aspartate retrograde transport to show a potentially EAAergic afferent from the intralaminar thalamic nuclei. ${ }^{26}$ AMPA, metabotropic. kainate, and NNKQ binding sites had high relative densities within the VP. Despite the apparently low density of NMDA binding sites, behavioral studies indicate that NMDA receptors may play a significant role in pallidal function. Turski et al. have demonstrated that intra-GP infusion of the NMDA antag. onist AP7 has significant effects on motor behavior. ${ }^{92}$

The EP has a low density of all EAA binding sites with a particularly low density of NMDA binding sites. As with the GP, the low density of EAA binding sites could be due in part to the low cellular density of the EP and the fact that it is embedded within the fibers of the heavily myelinated internal capsule. Functional EAA receptors exist within the EP. Injection of EAA antagonists within the EP of primates and rodents has potent effects on motor function. ${ }^{51.76}$ The EP receives a substantial EAAergic input from the STN.

The STN itself is known to receive a prominent projection from the neocortex. ${ }^{1}$ Extracellular recording studies have established that the cortico-STN projection is responsible for a rapid onset, short duration EAA-mediated excitatory postsynaptic potential in STN neurons, ${ }^{49,78.79}$ and the pharmacology of this fast excitatory postsynaptic potential is consistent with activation of kainate or AMPA receptors. ${ }^{78.79}$ These physiological results accord well with our binding data demonstrating a relatively high density of AMPA and kainate binding sites within the STN. Metabotropic binding sites are also relatively dense within the STN, suggesting that metabotropic receptors may be an important substrate for plastic changes in STN neuron function induced by cortical activity. While the relative density of NMDA binding sites in STN is low, a recent intracellular recording study indicated that NMDA receptors are involved in the afferent activation of STN neurons. ${ }^{63}$

The STN provides excitatory, EAAergic input to the VTA-SN, including both the pars reticulata and pars compacta. ${ }^{48.77}$ The VTA-SN may receive other EAAergic inputs. The existence of a corticonigral projection has been controversial, but tract-tracing studies indicate the presence of a frontal corticonigral projection which preferentially terminates on the pars compacta and VTA. ${ }^{710}$ Biochemical studies indicate that this projection is EAAergic. ${ }^{13.17 .52}$ The $\mathrm{SN}$ also receives an excitatory input from the pedunculopontine nucleus (PPN). ${ }^{81}$ The PPN nigral projection has been thought to be cholinergic." Scarnati et $\mathrm{al}$. however, have shown that SN neuron excitation induced by PPN stimulation is antagonized by EAA antagonists and not by the muscarinic anticholinergic scopolamine. ${ }^{82}$ The PPN projects also to the GP and EP. Recent studies of PPN connections indicate that non-cholinergic neurons closely adjacent to the cholinergic neurons of the PPN project to the GP. $\mathrm{EP}$, and $\mathrm{SN}{ }^{53}$ The PPN is another potential source of EAAergic innervation of the basal ganglia.

The $\mathrm{SN}$ is distinguished by the presence of a high relative density of metabotropic and NNKQ binding sites. The NNKQ site has also been found to be relatively abundant in human $\mathrm{SN} .{ }^{69}$ The functional significance of this binding site is presently unknown. Despite their low density, other types of EAA receptors may be important in SN-VTA function. Behavioral changes can be induced by intranigral infusion of kainate, NMDA, and AMPA ${ }^{5,72.73}$ Electrophysiological studies have demonstrated that nigral and VTA neurons are excited by NMDA and inhibited by NMDA antagonists, ${ }^{19,25,86}$ and NMDA enhances dopamine release from $\mathrm{SN}$ slice preparations. ${ }^{4}$ In rat mesencephalic cell cultures, EAA-stimulated dopamine release is attenuated by both NMDA and non-NMDA antagonists. ${ }^{6}$ Kalivas et al. have suggested that NMDA and kainate receptors are differentially located on different subpopulations of mesencephalic dopaminergic neurons. ${ }^{46}$ The preferential localization of NMDA receptors on dopaminergic nigrostriatal neurons is supported by the recent finding that NMDA receptors are preferentially depleted in the $\mathrm{SN}$ of Parkinson's disease victims.

\section{Clinical implications}

Our binding studies have potential clinical implications. The presence of EAA binding sites within all nuclei of the basal ganglia suggests that EAAergic agents could be used therapeutically to modify basal ganglia function. Several groups have suggested that agents interacting with EAA receptors might be useful in pharmacotherapy of Parkinson's disease, ${ }^{12.28,50,66,84}$ and Carlsson and Carlsson have shown that systemic administration of the non-competi- 
tive NMDA antagonist $\{(+)-5$-methyl-10,11-dihydro-5H-dibenzo[a,d]cyclohepten 5,10-iminemaleate (MK-801) to catecholamine-depleted mice increases motor activity." Injection of competitive or noncompetitive NMDA antagonists into the striatum produces an increase in motor activity similar to that seen with dopamine agonists, ${ }^{11,22,84,85}$ and infusion of NMDA antagonists into the EP, STN, or SN potentiates the effect of L-DOPA in monoamine-depleted rats. $^{51}$ The clinical usefulness of modifying the activity of non-striatal basal ganglia nuclei with systemically administered EAA antagonists may, however, be limited by the relatively low density of EAA binding sites in the GP, VP, EP, SN, VTA, and STN. The high density of EAA binding sites in other forebrain regions suggests that toxic effects might occur before therapeutic benefit is obtained from blockade of EAA receptors in non-striatal basal ganglia nuclei. The striatum-nucleus accumbens-OT complex, with its high density of binding sites, seem- ingly offers a better target for pharmacological intervention.

\section{CONCLUSION}

We have demonstrated the presence of EAA binding sites in all nuclei of the basal ganglia. The distribution of EAA binding sites was heterogeneous both within and between basal ganglia nuclei. While the presence of binding sites in receptor binding assays does not guarantee the presence of neurotransmission mediated by that receptor, ${ }^{42}$ our results suggest that EAA-mediated neurotransmission within the basal ganglia has a complex and heterogeneous character.

Acknowledgements - We thank Kevin O'Mara for assistance with figure preparation. This work was supported by grants NS19613, NS01300, the Huntington's Disease Society of America, and the Kenneth E. Campbell Foundation.

\section{REFERENCES}

1. Afsharpour S. (1985) Topographical projections of the cerebral cortex to the subthalamic nucleus. J. comp. Neurol. 236, 14-28.

2. Albin R. L., Aldridge J. W., Young A. B. and Gilman S. (1989) Feline subthalamic nucleus neurons contain glutamate-like but not GABA-like or glycine-like immunoreactivity. Brain Res. 491, 185-188.

3. Alheid G. F. and Heimer L. (1988) New perspectives in basal forebrain organization of special relevance for neuropsychiatric disorders: the striatopallidal, amygdaloid, and corticopetal components of substantia innominata. Neuroscience 27, 1-39.

4. Araneda R. and Bustos G. (1989) Modulation of dendritic release of dopamine by $N$-methyl-D-aspartate receptors in rat substantia nigra. $J$. Neurochem. 52, 962-970.

5. Arnt J. (1981) Turning behavior and catalepsy after injection of excitatory amino acids into rat substantia nigra. Neurosci. Lett. 23, 337-342.

6. Arqueros L., Abarca J. and Bustos G. (1985) Release of D- $\left[{ }^{3} \mathrm{H}\right]$ aspartic acid from the rat striatum: effect of veratridine evoked depolarization, fronto-parietal cortex ablation, and striatal lesions with kainic acid. Biochem. Pharmac. 34, $1217-1224$

7. Beckstead R. M. (1979) An autoradiographic examination of corticocortical and subcortical projections of the mediodorsal-projection (prefrontal) cortex in the rat. J. comp. Neurol. 184, 43-62.

8. Beckstead R. M. (1983) A reciprocal axonal connection between the subthalamic nucleus and the neostriatum in the cat. Brain Res. 275, 137-142.

9. Brown V. J. and Robbins T. W. (1989) Elementary processes of response selection mediated by distinct regions of the striatum. J. Neurosci. 9, 3760-3765.

10. Bunney B. S. and Aghajanian G. K. (1976) The precise localization of nigral afferents in the rat as determined by a retrograde tracing technique. Brain Res. 117, 423-435.

11. Carlsson M. and Carlsson A. (1989) The NMDA antagonist MK-801 causes marked locomotor stimulation in monoamine-depleted mice. J. Neural Trans. 75, 221-226.

12. Carlsson M. and Carlsson A. (1990) Interactions between glutamatergic and monoaminergic systems within the basal ganglia-implications for schizophrenia and Parkinson's disease. Trends Neurosci. 13, 272-276.

13. Carter C. J. (1982) Topographical distribution of possible glutamatergic pathways from the frontal cortex to the striatum and substantia nigra in rats. Neuropharmacology 21, 379-383.

14. Cha J. J., Makowiec R. L., Penney J. B. and Young A. B. (1990) L-[ $\left.{ }^{3} \mathrm{H}\right]$ Glutamate labels the metabotropic excitatory amino acid receptor in rodent brain. Neurosci. Lett. 113, 78-83.

15. Cheramy A., Romo R. and Glowinski J. (1990) The relative roles of neuronal activity and direct presynaptic mechanisms in controlling the release of dopamine from the cat caudate nucleus. In Annals of the New York Academy of Sciences, pp. 80-91.

16. Cherubini E., Herrling P. L., Lanfumey L. and Stanzione P. (1988) Excitatory amino acids in synaptic excitation of rat striatal neurones in vitro. $J$. Physiol. 400, 677-690.

17. Christie M. J., Bridge S., James L. B. and Beart P. M. (1985) Excitotoxin lesions suggest an aspartatergic projection from rat medial prefrontal cortex to ventral tegemental area. Brain Res. 333, 169-172.

18. Christie M. J., James J. B. and Beart P. M. (1985) An excitant amino acid projection from the medial prefrontal cortex to the anterior part of nucleus accumbens in the rat. $J$. Neurochem. 45, 477-482.

19. Collingridge G. L. and Davies J. (1978) An evaluation of D-alpha-aminoadipate and D-(and DL)alpha-aminosuberate as selective antagonists of excitatory amino acids in the substantia nigra and mesencephalic reticular formation of the rat. Neuropharmacology 18, 193-199.

20. Collingridge G. L. and Singer W. (1990) Excitatory amino acid receptors and synaptic plasticity. Trends pharmac. Sci. 11, 290-296. 
21. Dinopoulos A., Dori I., Davies S. W. and Parnavelas J. G. (1989) Neurochemical heterogeneity among corticofugal and callosal projections. Expl Neurol. 105, 36-44.

22. Donzanti B. A. and Uretsky N. J. (1984) Antagonism of the hypermotility response induced by excitatory amino acids in the rat nucleus accumbens. Archs Pharmac. 325, 1. 7.

23. Errami M. and Nieoullon A. (1988) alpha- $\left[{ }^{3} \mathrm{H}\right]$ Amino-3-hydroxy-5-methyl-4-isoxazolepropionic acid binding to rat striatal membranes: effects of selective brain lesions. J. Neurochem. 51, $579-586$.

24. Fonnum F., Storm-Mathisen J. and Divac I. (1981) Biochemical evidence for giutamate as neurotransmitter in corticostriatal and corticothalamic fibres in rat brain. Neuroscience 6, 863-873.

25. French E. D. (1986) Effects of phencyclidine on ventral tegmental Al0 dopamine neurons in the rat. Neuropharmacology 25, $241-248$.

26. Fuller T. A., Russchen F. T. and Price J. L. (1987) Sources of presumptive glutamatergic/aspartergic afferents to the rat ventral striatopallidal region. J. comp. Ncurol. 258, 317338.

27. Geary W. A., Toga A. W. and Wooten G. F. (1985) Quantatitive film autoradiography for tritium: methodological considerations. Brain Res. 337, 99-108.

28. Girault J.-A.. Halpain S. and Greengard P. (1990) Excitatory amino acid antagonists and Parkinson's disease. Trends Neurosci. 13, 325-326.

29. Girault J. A., Barbeito L., Sampinato U., Gozlan H., Glowinski J. and Besson M. J. (1986) In vivo release of endogenous amino acids from the rat striatum: further evidence for a role of glutamate and aspartate in corticostriatal neurotransmission. J. Neurochem. 47, 98-106.

30. Godukhin O. V., Zharikova A. D. and Novoselov V. I. (1980) The release of labeled L-glutamic acid from rat neostriatum in vivo following stimulation of frontal cortex. Neuroscience 5, 2151-2154.

31. Gould E., Woolf N. J. and Butcher L. L. (1989) Cholinergic projections to the substantia nigra from the pedunculopontine and laterodorsal tegmental nuclei. Neuroscience 28, 611-623.

32. Greenamyre J. T., Higgins D. S., Young A. B. and Penney J. B. (1990) Regional ontogeny of a unique glutamate recognition site in rat brain: an autoradiographic study. Int. $J$ dev/ Neurosci. $8,437-445$

33. Greenamyre J. T., Olsen J. M. M., Penney J. B. and Young A. B. (1985) Autoradiographic characterization of $N$-methyl-D-aspartate-, quisqualate- and kainate-sensitive glutamate binding sites. J. Pharmacl. exp. Ther. 233, 254-263.

34. Greenamyre J. T., Penney J. B., Young A. B., Hudson C., Silverstein F. S. and Johnston M. V. (1987) Evidence for transient perinatal glutamergic innervation of globus pallidus. J. Neurosci. 7, 10221030.

35. Greenamyre J. T. and Young A. B. (1989) Synaptic localization of striatal NMDA, quisqualate and kainate receptors Neurosci. Lett. 101, 133-137.

36. Groenewegen H. J. and Berendse H. W. (1990) Connections of the subthalamic nucleus with ventral striatopallidal parts of the basal ganglia in the rat. J. comp. Neurol. 294, 607-622.

37. Halpain S., Wieczorek C. M. and Rainbow T. C. (1984) Localization of L-glutamate receptors in rat brain by quantitative autoradiography. J. Neurosci. 4, 2247-2258.

38. Hammond C., Deniau J. M., Rizh A. and Feger J. (1978) Electrophysiological demonstration of an excitatory subthalamonigral pathway in the rat. Brain Res. 151, 235-244.

39. Hardy J. A., DeBelleroche J. S., Border D. and Bradford H. F. (1980) Differential transmitter release from nerve terminals isolated from basal ganglia and substantia nigra. J. Neurochem. 34, 1130-1139.

40. Hassler R., Haug P., Nitsch C., Kim J. S. and Paik K. (1982) Effect of motor and premotor cortex ablation on concentrations of amino acids, monoamines and acetylcholine and on the ultrastructure in rat striatum. A confirmation of glutamate as the specific cortico-striatal transmitter. $J$. Neurochem. 38, 1087-1098.

41. Hauber W. and Schmidt W. J. (1989) Effects of intrastriatal blockade of glutamatergic transmission on the acquisition of T-maze and radial maze tasks. J. Neural Trans. 78, 29-4I.

42. Herkenham M. (1987) Mismatches between neurotransmitter and receptor localizations in brain: observations and implications. Neuroscience 23, 1-38.

43. Herrling P. L. (1985) Pharmacology of the corticocaudate excitatory postsynaptic potential in the cat: evidence for jts mediation by quisqualate or kainate receptors. Neuroscience $14,417-426$.

44. Herrling P. L., Modris R. and Salt T. E. (1983) Effects of excitatory amino acids and their antagonists on membrane and action potentials of cat caudate neurones. J. Physiol., Lond. 339, 207-222.

45. Jaspers R. M. A., De Vries T. J. and Cools A. R. (1990) Enhancement in switching motor patterns following local application of the glutamate agonist AMPA into the cat caudate nucleus. Behav. Brain Res. 37, 237-246.

46. Kalivas P. W., Duffy P. and Barrow J. (1989) Regulation of the mesocorticolimbic dopamine system by glutamic acid receptor subtypes. J. Pharmac. exp. Ther. 251, 378-386.

47. Kincaid A. E., Newman S. W., Young A. B. and Penney J. B. (1989) Evidence for collateralization of the projection from parafascicular nucleus to globus pallidus and caudate-putamen in the rat. Soc. Neurosci. Abstr. 15, 288-288.

48. Kita H. and Kitai S. T. (1987) Efferent projections of the subthalamic nucleus in the rat: light and electron microscopic analysis with the PHA-L method. J. comp. Neurol. 260, 435-452.

49. Kitai S. T. and Deniau J. M. (1981) Cortical inputs to the subthalamus: intracellular analysis. Brain Res. 214, 411415

50. Klockgether T. and Turski L. (1989) Excitatory amino acids and the basal ganglia: implications for the therapy of Parkinson's disease. Trends Neurosci. 12, 285-286.

51. Klockgether T. and Turski L. (1990) $N$-Methyl-D-aspartate (NMDA) antagonists potentiate antiparkinsonian actions of L-dopa in monoamine depleted rats. Ann. Neurol. 28, 539-546.

52. Kornhuber J., Kim J. S., Kornhuber K. E. and Kornhuber H. H. (1985) The cortico-nigral projection: reduced glutamate content in substantia nigra following frontal cortex ablation in the rat. Brain Res. 322, 124-126.

53. Lee H. J., Rye D. B., Hallanger A. E., Levey A. I. and Wainer B. H. (1988) Cholinergic vs. noncholinergic efferents from the mesopontine tegmentum to the extrapyramidal motor system nuclei. J. comp. Neurol. 275, 469-492.

54. McGeer P. L.. McGeer E. G.. Scherer U. and Singh K. (1977) A glutamatergic corticostriatal path. Brain Res. 128, 369-373.

55. McGeorge A. J. and Faull R. L. M. (1989) The organization of the projection from the cerebral cortex to the striatum in the rat. Neuroscience 29, 503-537.

56. Monaghan D. T., Bridges R. J. and Cotman C. W. (1989) The excitatory amino acid receptors: their classes, pharmacology, and distinct properties in the function of the central nervous system. A. Rev: Pharmac. Toxicol. 29, $365-402$. 
57. Monaghan D. T. and Cotman C. W. (1982) The distribution of $\left[{ }^{3} \mathrm{H}\right]$ kainic acid binding in rat CNS as determined by autoradiography. Brain Res. 252, 91-100.

58. Monaghan D. T. and Cotman C. W. (1985) Distribution of $N$-methyl-D-aspartate-sensitive L-[ $\left.{ }^{3} H\right]$ glutamate-binding sites in rat brain. $J$. Neurosci. 5, 2909-2919.

59. Monaghan D. T., Olverman H. J., Nguyen L., Watkins J. C. and Colman C. W. (1988) Two classes of $N$-methyl-D-aspartate recognition sites: Differential distribution and differential regulation by glycine. Proc. natn. Acad. Sci. U.S.A. 85, 9836-9840.

60. Monaghan D. T, Yao D. and Cotman C. W. (1985) L- $[$ H H Glutamate binds to kainate-, NMDA-, and AMPA-sensitive binding sites: an autoradiographic analysis. Brain Res. 340, 378-383.

61. Mount H., Quirion R., Chaudieu I. and Boksa P. (1990) Stimulation of dopamine release from cultured rat mesencephalic cells by naturally occurring excitatory amino acids: involvement of both $N$-methyl-D-aspartate (NMDA) and non-NMDA receptor subtypes. $J$. Neurochem. 55, 268-275.

62. Nakanishi H., Kita H, and Kitai S. T. (1987) Intracellular study of rat substantia nigra pars reticulata neurons in an in vitro slice preparation: electrical membrane properties and response characteristics to subthalamic stimulation. Brain Kes. 437, 45-55.

63. Nakanishi H., Kita H. and Kitai S. T. (1988) An N-methyl-D-aspartate receptor mediated excitatory postsynaptic potential evoked in subthalamic neurons in an in vitro slice preparation of the rat. Neurosci. Lett. 95, $130-136$.

64. Nicoletti F., Wroblewski J. T., Alho H., Eva C., Fadda E. and Costa E. (1987) Lesions of putative glutamatergic pathways potentiate the increase of inositol phospholipid hydrolysis elicited by excitatory amino acids. Brain Res. 436, $103-112$.

65. Nieoullon A., Scarfone E., Kerkerian L., Errami M. and Dusticier N. (1985) Changes in choline acetyltransferase, glutamic acid decarboxylase, high affinity glutamate uptake and dopaminergic activity induced by kainic acid lesion of the thalamostriatal neurons. Neurosei. Lett. 58, 299-304.

66. Olney J. W., Price M. T., Labruyere J. W. et al. (1987) Anti-Parkinsonian agents are phencyclidine agonists and $N$-methyl-aspartate antagonists. Eur. J. Pharmac. 142, 319-320.

67. Pan H. S., Frey K. A., Young A. B. and Penney J. B. (1983) Changes in [ $\left.{ }^{3} \mathrm{H}\right]$ muscimol binding in substantia nigra, entopeduncular nucleus, globus pallidus, and thalamus after striatal lesions as demonstrated by quantitative receptor autc adiography. J. Neurosci. 3, 1189-1198.

68. Paxinos G. and Watson C. (1986) The Rat Brain in Stereotaxic Coordinates, 2nd edn. Academic Press, Oriando.

69. Penney J. B., Difazio M. C. and Young A. B. (1990) Glutamate binding sites in the substantia nigra of Parkinson's disease. Neurochem. Int. 16, 59-59.

70. Perschak H. and Cuenod M. (1990) In vivo release of endogenous glutamate and aspartate in the rat striatum during stimulation of the cortex. Neuroscience 35, 283-287.

71. Pisa M. and Cyr J. (1990) Regionally selective roles of the rat's striatum in modality-specific discrimination learning and forelimb reaching. Behav. Brain Res. 37, 281-292.

72. Porceddu M. L., Piacente B., Morelli M. and Dichiara G. (1979) Opposite turning effects of kainic and ibotenic acid injected in the rat substantia nigra. Neurosci. Lett. 15, 271-276.

73. Pycock C. J. and Dawbarn D. (1980) Acute motor effects of $N$-methyl-D-aspartic acid and kainic acid applied focally to mesencephalic dopamine cell body regions in the rat. Neurosci. Lett. 18, 85-90.

74. Rainbow T. C., Wieczorek C. M. and Halpain S. (1984) Quantitative autoradiography of binding sites for [ $\left.{ }^{3} \mathrm{H}\right] \mathrm{AMPA}$, a structural analogue of glutamic acid. Brain Res. 309, $173-177$.

75. Reubi J. C. and Cuenod M. (1979) Glutamate release in vitro from corticostriatal terminals. Brain Res. 176, 185-188.

76. Robertson R. G., Farmery S. M., Sambrook M. A. and Crossman A. R. (1989) Dyskinesia in the primate following injection of an excitatory amino acid antagonist into the medial segment of the globus pallidus. Brain Res. 476, 317-322.

77. Robledo P. and Feger J. (1990) Excitatory influence of rat subthalamic nucleus to substantia nigra pars reticulata and the pallidal complex: electrophysiological data. Brain Res. 518, 47-54.

78. Rouzaire-Dubois B. and Scarnati E. (1987) Increase in glutamate sensitivity of subthalamic nucleus neurons following bilateral decortication: a microiontophoretic study in the rat. Brain Res. $403,366-370$.

79. Rouzaire-Dubois B. and Scarnati E. (1987) Pharmacological study of the cortical-induced excitation of subthalamic nucleus neurons in the rat: evidence of amino acids as putative neurotransmitters. Neuroscience 21, 429-440.

80. Rowlands G. J. and Roberts P. J. (1980) Specific calcium-dependent release of endogenous glutamate from rat striatum is reduced by destruction of the cortico-striatal tract. Expl Brain Res. 39, 239-240.

81. Scarnati E., Campana E. annd Pacitti C. (1984) Pedunculopontine-evoked excitation of substantia nigra neurons in the rat. Brain Res. 304, 351-361.

82. Scarnati E., Proia A., Campana E. and Pacitti C. (1986) A microiontophoretic study on the nature of the putative synaptic neurotransmitter involved in the pedunculopontine-substantia nigra pars compacta excitatory pathway of the rat. Expl Brain Res. 62, 470-478.

83. Schmidt B. H., Weiss S., Sebben M., Kemp D. E., Blockaert J. and Sladeczek F. (1987) Dual action of excitatory amino acids on the metabolism of inositol phosphates in striatal neurons. Molec. Pharmac. 32, 364-368.

84. Schmidt W. J. and Bubser M. (1989) Anticataleptic effects of the $N$-methyl-D-aspartate antagonist MK-801 in rats. Pharmac. Biochem. Behav. 32, 621-623.

85. Schmidt W. J. and Bury D. (1988) Behavioral effects of $N$-methyl-D-aspartate in the anterodorsal striatum of the rat. Life Sci. 43, 545-549.

86. Sutin V., Verbanck P., Massotte L. and Dresse A. (1990) Evidence for the presence of $N$-methyl-D-aspartate receptors in the ventral tegmental area of the rat: an electrophysiological in vitro study. Brain Res. 514, 147-150.

87. Sladeczek F., Recasens M. and Bockaert J. (1988) A new mechanism for glutamate receptor action: phosphoinositide hydrolysis. Trends Neurosci. 11, 545-549.

88. Smith Y., Hazrati L. N. and Parent A. (1990) Efrerent projections of the subthalamic nucleus in the squirrel monkey as studied by the PHA-L anterograde tracing method. J. comp. Neurol. 294, 306-323.

89. Spencer H. J. (1976) Antagonism of cortical excitation of striatal neurons by glutamic acid diethyl ester: evidence for glutamic acid as an excitatory transmitter in the rat striatum. Brain Res. 102, 91-101.

90. Stone T. W. (1979) Amino acids as neurotransmitters of corticofugal neurones in the rat: a comparison of glutamate and aspartate. Br. J. Pharmac. 67, 545-551. 
91. Streit P. (1980) Selective retrograde labeling indicating the transmitter of neuronal pathways. J. comp. Neurol. 191, $429-463$.

92. Turski L., Klockgether T., Turski W. A., Schwarz M. and Sontag K. H. (1990) Blockade of excitatory neurotransmission of the globus pallidus induces rigidity and akinesia in the rat: implications for excitatory neurotransmission in pathogenesis of Parkinson's diseases. Brain Res. 512, 125-131.

93. Unnerstall J. R. and Wamsley J. K. (1983) Autoradiographic localization of high-affinity [ $\left.{ }^{3} \mathrm{H}\right] \mathrm{kainic}$ acid binding sites in the rat forebrain. Eur. J. Pharmac. 86, 361--371.

94. Walaas I. (1981) Biochemical evidence for overlapping neocortical and allocortical glutamate projections to the nucleus accumbens and rostral caudatoputamen in the rat brain. Neuroscience 6, 399-401.

95. Walaas I. and Fonnum F. (1979) The effects of surgical and chemical lesions on neurotransmitter candidates in the nucleus accumbens of the rat. Neuroscience 4, 209-216.

96. Weiss S. (1989) Two distinct quisqualate receptor systems are present on striatal neurons. Brain Res. 491, 189-193.

97. Worley P. F., Baraban J. M. and Snyder S. H. (1989) Inositol 1,4,5-trisphosphate receptor binding: autoradiographic localization in rat brain. $J$. Neurosci. 9, 339-346.

98. Young A. B. and Fagg G. E. (1990) Excitatory amino acid receptors in the brain: membrane binding and receptor autoradiographic approaches. Trends pharmac. Sci. 11, 126-133.

(Accepted 19 April 1991) 